\title{
Perbedaan Pengaruh Edukasi antara Film dan Ceramah Terhadap Pengetahuan dan Sikap Deteksi Dini Kanker Serviks Ibu-Ibu di Dusun Krodan Sleman
}

\section{Differences Between The Effect of Educational Film and Lecture on Knowledge and Attitudes of Early Detection of Cervical Cancer in Women's Krodan Village, Sleman.}

Paulina Ratnaningrum

Fakultas Farmasi, Universitas Sanata Dharma

Yogyakarta

\begin{abstract}
Intisari
Kanker serviks adalah tumor ganas yang tumbuh di dalam leher rahim atau serviks yang disebabkan oleh human papillomavirus (HPV). Kanker serviks merupakan pembunuh nomor satu bagi perempuan. Menurut data yang didapat dari Yayasan Kanker Indonesia (2007) menyebutkan bahwa setiap tahunnya sekitar 500.000 perempuan terdiagnosa menderita kanker serviks dan lebih dari 250.000 meninggal dunia. Salah satu pencegahan kanker serviks dapat dilakukan dengan papsmear. Papsmear dapat menurunkan angka kematian penderita serviks hingga mencapai 50-60\%.

Penelitian ini memiliki tujuan mengetahui perbedaan pengaruh edukasi antara media film dan ceramah terhadap pengetahuan dan sikap deteksi dini kanker serviks. Metode penelitian ini adalah eksperimental semu (quasi experimental research) dengan rancangan penelitian pre-posttest intervention with control group. Teknik pengambilan data dengan kuesioner dan dianalisis dengan program komputer.

Hasil analisis statistik menggunakan Independent Samples T-test menunjukkan bahwa terdapat perbedaan peningkatan pengetahuan dan sikap yang signifikan antara kelompok film dengan ceramah terhadap deteksi dini kanker serviks $(p=0,002)$, dimana media ceramah lebih efektif daripada film.
\end{abstract}

Kata kunci : papsmear, pengetahuan, sikap, ceramah, film

\section{Abstract}

Cervical cancer is a malignant tumor that grows in the cervix are caused by Human Papillomavirus (HPV). Cervical cancer is the number one killer for women. According to data obtained from the Indonesian Cancer Foundation (2007) each year about 500.000 women diagnosed with cervical cancer and more than 250.000 died. Cervical cancer prevention can be done with papsmear. Papsmear can reduce cervical cancer mortality up to $50-60 \%$.

This research had pupose to know the difference influence education between movie and lecture to the knowledge and attitude on early detection of cervical cancer. This study was a quasi-experimental research with the design of pre-posttest intervention study with control group. The data was collected by using questionnaires and analyzed by using computer programs. 
The statistic analysis with Independent Sampels T-test showed significantly different increased of knowledge and attitude betwen movie and lecture on early detection of cervical cancer $(p=0,002)$. Lecture was more effective than movie.

\section{Key words : papsmear, knowledge, attitude lecture, movie}

\section{Pendahuluan}

Kanker serviks (cervix cancer) atau lebih dikenal dengan kanker leher rahim adalah tumor ganas yang tumbuh di dalam leher rahim atau serviks, dimana sekitar 90-99\% disebabkan oleh Human Papillomavirus (HPV). Serviks merupakan organ yang menghubungkan antara uterus dengan vagina (National Cancer Institude, 2007).

Kanker serviks merupakan pembunuh nomor satu bagi perempuan sebelum kanker payudara. Salah satu pencegahan kanker serviks adalah dengan papsmear. Data yang diperoleh pada negara-negara maju yang telah menggunakan metode deteksi dini kanker serviks seperti papsmear menunjukkan penurunan terhadap angka kematian kanker serviks hingga mencapai 50-60\% (Wijayanti, 2008). Berdasarkan data WHO tahun 2008 perempuan di negara berkembang sepeti Indonesia hanya sekitar 5\%, sedangkan di negara maju sekita $70 \%$ perempuan telah melakukan papsmear. Salah satu faktor yang menyebabkan adalah ketidakmerataan informasi tentang deteksi dini kanker serviks. Pemberian informasi kesehatan merupakan salah satu peran dari seorang farmasis melalui pemberian promosi kesehatan (health promotion).

Metode edukasi kesehatan dapat dilakukan dengan berbagai cara meliputi poster, gambar, foto, koran, pemutaran film, penyuluhan lewat radio, ceramah, pidato, dan demonstrasi. Metode film merupakan salah satu metode edukasi karena media film ini dinilai lebih dapat menghibur tetapi juga berisi pesan-pesan yang bersifat mendidik (Depkes RI, 2004). Media ceramah merupakan media yang dapat memberikan pengetahuan secara lisan kepada masyarakat untuk sasaran yang berpendidikan tinggi maupun rendah (Notoatmodjo, 1993).

Kanker serviks sangat rentan terjadi pada wanita yang sudah menikah yaitu ibu- ibu dengan rentan usia 35-55 tahun. Namun, terdapat data lainnya yang menyebutkan kanker serviks juga dapat terjadi pada wanita di bawah usia 35 tahun yang memiliki faktor resiko kanker serviks. Banyak ibu-ibu yang belum mengetahui tentang deteksi dini kanker serviks. Dusun Krodan, Sleman merupakan salah satu daerah yang belum pernah dilakukan pemberian edukasi dan penelitian mengenai deteksi dini kanker serviks. Informasi tentang deteksi dini kanker serviks sangat berguna untuk ibu-ibu sehingga dapat digunakan untuk dirinya sendiri, oranglain, atau bahkan anak perempuannya. Maka diharapkan dengan adanya pemberian edukasi mengenai deteksi dini kanker serviks ini kepada ibu-ibu di dusun krodan sleman dapat meningkatkan pengetahuan dan sikap akan kesadaran deteksi dini kanker serviks sehingga diharapkan lebih banyak lagi perempuan yang sadar akan deteksi dini kanker serviks.

\section{METODE PENELITIAN}

Penelitian ini merupakan jenis penelitian eksperimental murni (quasi experimental research) dengan rancangan penelitian pre-posttest intervention with control group design.

\section{A. Tempat dan Waktu penelitian}

Penelitian dilakukan di Dusun Krodan, Sleman (di rumah ibu RT 03, 01, dan 07). Waktu penelitian: Juni 2011 sampai Desember 2011.

\section{B. Bahan penelitian}

1. Populasi yang digunakan dalam penelitian ini adalah ibu-ibu di dusun, krodan, sleman DIY.

2. Sampel yang digunakan pada penelitian ini adalah ibu-ibu di Dusun Krodan, 
Sleman dengan persyaratan yaitu ibu-ibu yang mewakili masing-masing RT di Dusun Krodan Sleman, telah menikah, dan bersedia mengikuti edukasi dari awal sampai akhir, mengisi dan Pada tabel 1, menunjukkan kelompok yang menjadi kelompok intervensi berdasarkan sistem undian (random) adalah Kontrol : RT 03 (Timbulrejo), media film : RT 01 (Krodan), dan media ceramah : RT 07 (kepuhsari). mengsembalikan kuesioner yang diberikan.

3. Teknik sampling yang digunakan adalah Mutistage Sampling berdasarkan RT kombinasi purposive sampling.

4. Kuesioner

Kuesioner yang digunakan adalah kuesioner dengan skala likret. Penyusunan kuesioner mengacu pada pedoman National Cancer Institude (2007).

Tabel I. Daftar wilayah dalam masing-masing perlakuan

\begin{tabular}{lll}
\hline & Daftar Wilayah Perlakuan & \\
\hline RT 03 & RT 01 & RT 05 \\
RT 04 & RT 02 & RT 06 \\
RT 13 & RT 10 & RT 07 \\
RT 14 & RT 11 & RT 08 \\
RT 15 & RT 12 & RT 09 \\
\hline
\end{tabular}

Tabel II Profil pernyataan pada National Cancer Institude (2007)

\begin{tabular}{lrl}
\hline No. & \multicolumn{1}{c}{ Pernyataan } \\
\hline 1. & Pengukuran aspek pengetahuan: \\
a. & Definisi penyakit kanker serviks \\
b. & Etiologi penyakit kanker serviks \\
c. & Tanda dan gejala penyakit kanker serviks \\
d. & Faktor resiko penyakit kanker serviks \\
e. & Upaya pencegahan penyakit kanker serviks \\
f. & Pengertian papsmear \\
g. & Arti pentingnya melakukan papsmear \\
h. & Kapan sebaiknya waktu yang ideal untuk papsmear \\
\hline 2. Pengukuran aspek sikap & \\
a. & Pendapat tentang ancaman kanker serviks pada penurunan kualitas hidup \\
b. & Upaya pencegahan kanker serviks \\
c. & Pendapat tentang deteksi kanker serviks \\
d. & Pendapat tentang hal yang menghambat (kerugian) deteksi dini dengan papsmear \\
e. & Pendapat tentang hal yang mendukung (keuntungan) deteksi dini dengan papsmear \\
f. & Pendapat tentang tempat melakukan papsmear \\
g. & Pendapat tentang biaya melakukan papsmear
\end{tabular}

\section{Tata Cara Penelitian}

1. Perijinan

2. Penelusuran data populasi

3. Pembuatan kuesioner

a. Penyusunan dan pembuatan kuesioner

Kuesioner terdiri dari 2 bagian, bagian pertama mengenai karakteristik demografi responden dan bagian kedua berupa kuesioner yang terdiri atas aspek pengetahuan (10 pernyataan) dan sikap (10 pernyataan). Penyusunan kuesioner mengacu pada pedoman National Cancer Institude (2007).

b. Uji validasi

Uji validitas dilakukan dengan membagikan kuesioner pada ibu-ibu di Dusun Kebur Kidul, Cangkringan dan dihitung validitasnya. Hasil uji validitas 
pada masing-masing pernyataan dimana r tabel 0,632 adalah diperoleh 8 butir pernyataan yang valid dan 12 pernyataan yang belum valid. Kemudian 12 pernyataan yang belum valid dilakukan professional adjustment agar diperoleh hasil yang valid.

c. Uji reliabilitas

Metode yang digunakan untuk mengetahui kuesioner telah realibel adalah dengan melihat Cronbach's alpha. Dari hasil pengukuran diperoleh nilai koefisien reliabilitas $=0,811(>0.06)$ yang berarti kuesioner memiliki reliabilitas yang baik.

4. Pelaksanaan intervensi

a. Publikasi kegiatan :

b. Pelaksanaan kontrol : Pelaksanaan dilakukan dengan pembagian dan pengisian kuesioner tanpa dilakukan intervensi. .

c. Pelaksanaan intervensi film : Pelaksanaan dimulai dengan pretest, dilanjutkan dengan pemutaran film dan terakhir posttest.

d. Pelaksanaan ceramah : Pelaksanaan dimulai dengan pretest, dilanjutkan ceramah dan posttest.

e. Posttest satu bulan setelah intervensi : Posttest kedua diberikan 1 bulan setelah intervensi.

5. Pengambilan data

Pada kelompok intervensi (film dan ceramah) terdapat 3 data meliputi pretest, posttest (setelah intervensi) dan posttest (1 bulan setelah intervensi). Sedangkan pada kelompok kontrol terdapat 2 data yaitu kuesioner I dan kuesioner ke II (setelah 1 bulan)

6. Tata cara analisis data

a. Proses manajemen data, meliputi editing, processing, dan cleaning

b. Analisis data, meliputi :

1). Uji normalitas data, dengan program komputer menggunakan uji Shapiro-wilk.
2). Paired T-test
3). Independent T-test
4). Metode kolmogorov-smirnov

Pengetahuan merupakan dasar atau pedoman seseorang untuk bersikap dan berperilaku (Azwar, 2005). Pengetahuan yang dimaksud pada penelitian ini adalah tingkat pemahaman responden terhadap deteksi dini kanker serviks. Sikap merupakan respon tertutup seseorang terhadap obyek tertentu (Sarwono, 2007). Sikap pada penelitian ini adalah respon dari responden terhadap deteksi dini kanker serviks.

Kuesioner digunakan sebagai alat ukur untuk mengetahui tingkat pengetahuan dan sikap responden terhadap deteksi dini kanker serviks. Kuesioner terdapat 20 pernyataan dimana masing-masing 10 pernyataan mewakili pengetahuan dan 10 pernyataan mewakili sikap.

A. Pengaruh Edukasi terhadap peningkatan pengetahuan dan sikap tentang deteksi dini kanker serviks sebelum dan setelah pemberian edukasi baik film maupun ceramah.

Pada kelompok perlakuan (film dan ceramah) dilakukan 3 kali pengambilan data yaitu pretest, posttest, dan posttest setelah 1 bulan. Data yang diperoleh dari kuesioner dilakukan uji normalitas terlebih dahulu. Analisis data yang digunakan adalah dengan program komputer menggunakan uji Shapiro-wilk karena sample yang digunakan kecil $(\leq 50)$. Uji dilakukan dengan memasukkan data prestest dan posttest. Hasil uji normalitas aspek pengetahuan dan sikap dengan uji uji Shapirowilk menunjukkan bahwa pada kelompok perlakuan dengan film dan ceramah untuk pretest dan posttest berdistribusi normal $(\mathrm{p}>0,05)$ sehingga digunakan analisis statistik Paired T-test (Dahlan, 2005).

Berdasarkan tabel III. menunjukkan terdapat perbedaan pengetahuan dan sikap yang signifikan antara sebelum dan setelah edukasi baik dengan media film maupun ceramah $(\mathrm{p}<0,05)$. Peningkatan pengetahuan dan sikap ini didasarkan atas kesadaran dan kemauan individu masyarakat yang tidak sekedar melibatkan perubahan gerakan, melainkan juga menyangkut perubahan persepsi terhadap tindakan yang dianjurkan (Sarwono, 2007). Dengan adanya penyampaian edukasi baik melalui film dan ceramah mengenai deteksi dini kanker serviks dapat meningkatkan pengetahuan dan sikap responden.

\section{PEMBAHASAN}


Tabel III. Hasil uji perbandingan nilai pengetahuan dan sikap kelompok film dan ceramah sebelum dan setelah edukasi dan nilai signifikansi dengan Paired $T$-test

\begin{tabular}{ccccc}
\hline kelompok & variabel & sebelum & setelah & P \\
\hline \multirow{2}{*}{ Film } & Pengetahuan & 28,7 & 32,1 & Signifikan \\
\cline { 2 - 5 } & Sikap & 30,3 & 33,2 & Signifikan \\
\hline \multirow{2}{*}{ ceramah } & Pengetahuan & 26,6 & 34,3 & Signifikan \\
\cline { 2 - 5 } & Sikap & 29,8 & 34,7 & Signifikan \\
\hline
\end{tabular}

Peningkatan pengetahuan setelah satu bulan dapat diketahui dengan menggunakan data rerata selisih pretest-posttest dan pretestposttest 1 bulan. Hasil uji normalitas rerata selisih nilai pengetahuan dan sikap antara pretest-posttest dengan pretest-posttest 1 bulan menunjukkan bahwa data berdistribusi normal karena memiliki $\mathrm{p}>0,05$ sehingga analisis data yang digunakan adalah Paired $T$ test. (Dahlan, 2005)

Tabel IV. Hasil rerata selisih nilai pengeahuan dan sikap antara pretest-posttest dengan pretestposttest 1 bulan dan nilai signifikansi dengan Paired T-test

\begin{tabular}{|c|c|c|c|c|}
\hline \multirow[t]{2}{*}{ Kelompok } & \multirow[t]{2}{*}{ Variabel } & \multicolumn{2}{|c|}{ Rerata selisih } & \multirow[t]{2}{*}{$\mathrm{p}$} \\
\hline & & Pretest-posttest & $\begin{array}{l}\text { Pretest-posttest } 1 \\
\text { bulan }\end{array}$ & \\
\hline \multirow[t]{2}{*}{ Film } & Pengetahuan & 3,4 & 1,7 & Signifikan \\
\hline & Sikap & 2,9 & 1,4 & Tidak Signifikan \\
\hline \multirow[t]{2}{*}{ ceramah } & Pengetahuan & 7,8 & 7,7 & Tidak Signifikan \\
\hline & Sikap & 5,0 & 3,5 & Signifikan \\
\hline
\end{tabular}

Berdasarkan tabel IV pada kelompok film dan ceramah terjadi peningkatan nilai pengetahuan dan sikap setelah diberikan edukasi dengan film yang ditunjukkan rerata selisih yang bernilai positif. Apabila pretestposttest dibandingkan dengan pretest-posttest 1 bulan pada aspek pengetahuan terjadi penurunan yang signifikan untuk kelompok dengan intervensi film, dan penurunan yang tidak signifikan pada kelompok ceramah. Pada aspek sikap terjadi penurunan yang tidak signifikan pada kelompok film dan penurunan yang signifikan pada kelompok ceramah.

Penurunan nilai pengetahuan dan sikap setelah satu bulan menunjukkan daya ingat dari responden setelah satu bulan tentang deteksi dini kanker serviks. Berdasarkan Notoadmodjo (1993) pemberian edukasi perlu dilakukan berulang-ulang agar responden benar-benar memahami edukasi yang diberikan.

\section{B. Perbedaan pengaruh media edukasi} dengan film dan ceramah terhadap

\section{peningkatan pengetahuan dan sikap deteksi dini kanker}

Berdasarkan analisis data dengan uji uji Shapiro-wilk menunjukkan bahwa selisih pretest-posttest dan pretest-posttest 1 bulan pada kelompok perlakuan (film dan ceramah) serta selisih antara pretest-posttest 1 bulan pada kelompok kontrol pada kedua variabel berdistribusi normal ( $>>0,05)$ sehingga analisis yang digunakan statistik Independent $t$ test.

Berdasarkan tabel $\mathrm{V}$, didapatkan hasil peningkatan nilai pengetahuan dan sikap pada kelompok ceramah dikarenakan edukasi ceramah yang diberikan, responden mampu mengingat materi edukasi yang diberikan setelah 1 bulan pemberian edukasi dengan ceramah, peningkatan nilai pengetahuan pada responden kelompok film dikarenakan edukasi film yang diberikan, terdapat perbedaan pengetahuan yang signifikasn dan sikap yang tidak signifikan antara kelompok film dan ceramah. 
Keefektifan media film dan ceramah dapat diketahui dengan membandingkan rerata selisih pengetahuan dan sikap antara pretest dan posttest setelah pemberian edukasi terhadap obyek penelitian (Prasetia, 2009).

Tabel V. Perbedaan signifikansi antara kelompok perlakuan dengan kontrol pada nilai pretestposttest

\begin{tabular}{lllllll}
\hline Variabel & \multicolumn{3}{c}{ Pretest-posttest } & \multicolumn{3}{c}{ Pretest-posttest 1 bulan } \\
\cline { 2 - 7 } & $\begin{array}{l}\text { Kontrol- } \\
\text { film }\end{array}$ & $\begin{array}{l}\text { Kontrol- } \\
\text { ceramah }\end{array}$ & $\begin{array}{l}\text { Film- } \\
\text { ceramah }\end{array}$ & $\begin{array}{l}\text { Kontrol- } \\
\text { film }\end{array}$ & $\begin{array}{l}\text { Kontrol } \\
\text { ceramah }\end{array}$ & $\begin{array}{l}\text { Film- } \\
\text { ceramah }\end{array}$ \\
\hline pengetahuan & S & S & S & TS & S & S \\
\hline Sikap & TS & TS & TS & TS & TS & TS \\
\hline
\end{tabular}

Keterangan : $\mathrm{S}=$ signifikan

Tabel VI. Perbandingan rerata selisih nilai pretest-posttest setelah perlakuan film dan ceramah dan hasil signifikansinya

\begin{tabular}{ccc}
\hline Kelompok & Rerata selisih & $\mathrm{p}$ \\
\hline Film & 6,32 & Signifikan \\
Ceramah & 12,7 & \\
\hline
\end{tabular}

Berdasarkan tabel VI terdapat perbedaan yang signifikan antara kelompok film dan ceramah dimana media ceramah lebih efekif dibandingkan film. Hal ini dikarenakan media ceramah terjadi diskusi dua arah dengan narasumber sedangkan media film tidak terjadi diskusi dua arah. Selain itu media film berupa alur cerita yang panjang, dimana cenderung membuat responden jenuh dan tidak memperhatikan keseluruhan isi film secara menyeluruh. Notoadmodjo (1993) menyatakan bahwa sesuatu yang dilihat dengan penuh perhatian akan memberikan pengertian baru dan dapat mendorong untuk melakukan sesuatu yang baru.

\section{KESIMPULAN}

1. Terdapat peningkatan yang signifikan sebelum dan setelah edukasi dengan film dan ceramah

2. Terdapat peningkatan sikap yang signifikan sebelum dan setelah edukasi dengan film dan ceramah

3. Secara statistik terdapat perbedaan yang signifikan pada kelompok film dan ceramah berdasarkan peningkatan pengetahuan dan sikap. Media ceramah lebih efektif dibandingkan dengan film.

\section{DAFTAR PUSTAKA}

American Cancer Society, 2010, Cervical Cancer,

http://www.cancer.org/acs/group s/cid/documents/webcontent/003 094-pdf.pdf, diakses tanggal 6 November 2011

American College of Obstetricks and Gynecology, 2009, ACOG Issues Revised Cervical Cancer Screening Guidelines,

http://www.cancer.org/Cancer/ne ws/News/acog-revises-cervicalcancer-screening-guidelines, diakses tanggal 4 Mei 2011

Astana, M., 2009, Bersahabat dengan kanker : Panduan Mengelola dan Mengobati Kanker, Araska, Yogyakarta

Aziz, M. F., Masalah pada Kanker Serviks, Cermin Dunia Kedokteran, pp5-8

Azwar, 2005, Sikap Manusia Teori dan Pengukurannya, edisi kedua, Pustaka Pengajar, Yogyakarta, pp 3-37 
Azwar, 2009, Reliabilitas dan Validasi, Pustaka Pengajar, Yogyakarta, pp 4-9

Azwar, 2010, Metode Penelitian Pustaka Pengajar, Yogyakarta, pp 105-106

Corwin, E.J., 2009, Buku Saku Patofisiologi, ECG Kedokteran, Jakarta, pp 6667

Dahlan, M.S., 2009, Statistik untuk Kedokteran dan Kesehatan, Salemba Medika, Jakarta

Depkes RI, 2004, Metode dan Media Promosi Kesehatan, Depkes RI, http://www.pamsimas.org/index. php?option $=$ com phocadownload \&view $=$ category\&id $=48$ :pedumstrategilts\&download $=296$ : metodedan-media\&Itemid=12, diakses tanggal 26 Maret 2011

Hasan, M.O., Pokok Metodologi Penelitian dan Aplikasinya, Ghalia Indonesia, Jakarta

Kurniawan, A., 2011, SPSS Serba Serbi Analisis Statistika dengan Cepat dan Mudah, Jasakom, Jakarta

McQuail, D., 1987,Teori Komunikasi Massa : Suatu Pengantar Edisi Kedua, Penerbit Erlangga, Jakarta

Nawawi, H., 2007, Metodologi Penelitian Sosial, Cetakan 12, Gadjah Mada University Press, Yogyakarta, pp 141-144, 164

Narasty, 2009, Perbedaan Pengaruh Ceramah dan Ceramah-Testimoni tentang Kanker Serviks dan Papsmear terhadap Perilaku Guru Wanita Sekolah Dasar di Kota Yogyakarta, Skripsi, Universitas Sanata Dharma, Yogyakarta

National Cancer Institute, 2007, Cervical Cancer,http://www.cancer.gov/can certopic/cancerlibrary/what-iscancer diakses tanggal 4 Mei 2011

Notoatmodjo, S., 1993, Pengantara Pendidikan Kesehatan dan Ilmu Perilaku Kesehatan, 39,53, Penerbit ANDI OFFSET, Yogyakarta

Notoatmodjo, S., 2010a, Ilmu Perilaku Kesebatan, 27, Penerbit PT RINEKA CIPTA, Jakarta
Notoatmodjo, S., 2010b, Metodologi Penelitian Kesehatan, Penerbit PT RINEKA CIPTA, Jakarta

Pratiknya, A. W., 2001, Dasar-dasar Metodologi Penelitian Kedokteran dan Kesehatan, Raja Grafindo Perkasa, Jakarta

Prasetia, M.F.E., 2009, Penggunaan Video Pembelajaran dalam Upaya Meningkatkan Effektifitas Hasil Belajar Siswa Kelas VIII pada Mata Pelajaran Teknologi Informatika dan Komunikasi, Skripsi, Universitas Pendidikan Indonesia, Bandung

Purnomo, 2010, Perbedaan Pengaruh Ceramah dan Pemberian Leaflet tentang Kanker Serviks dan Test Papsmear terhadap Perilaku ibu-ibu PKK Kota Yogyakarta dengan Latar Belakang Perbedaan Usia, Skripsi, Universitas Sanata Dharma Yogyakarta

Sarwono, S, W., 2007, Sosiologi Kesehatan, Gadjah Mada University Press, Yogyakarta, pp 9-14

Sugiyono, 2008, Statistika untuk Penelitian, 74, Penerbit Alfabeta, Bandung, pp. $9-14$

Sukaca, B, E., 2009, Cara Cerdas Menghadapi Kanker Serviks (Leher Rahim), Genius Printika, Yogyakarta, pp. 12-20, 37-49, 87-98

United States Preventative Services Task Force, 2003, Risk Factor and Other Epidemiologic Considerations for Cervical Cancer Screening : A Narrative Review for the US Preventive Services Task Force, http://www.uspreventiveservi cesforce.org/uspstf/uspscerv.html, diakses tanggal 4 Mei 2011

Wijayanti, K., 2008, Pencegahan Kanker Serviks dengan Imunisasi HPV, Medika Jurnal Kedokteran Indonesia, pp. 643-646 